\title{
THE DEMOGRAPHY AND CURRENT WORK CONDITIONS OF CAMEROONIAN PROFESSIONAL JOURNALISTS
}

\author{
Peter Tiako Ngangu \\ Centre for Information and Communications Research Université Libre Brussels, Belgium
}

\begin{abstract}
Drawing on a national survey, this study examines the demography and current working conditions of Cameroonian professional journalists. Journalism appears to be a young person's profession in Cameroon. Also, journalism education is increasingly being seen as professionally relevant to entrylevel and mid-career journalists looking to improve and upgrade their qualifications. Drawing from the results of the survey, journalism is a very demanding profession in Cameroon. It requires working at night and for long hours out of home. Also, like in many parts of the world, journalism is not lucrative in Cameroon. Interviews with journalists revealed that a variety of constraints are adversely affecting the context under which journalists operate. Most journalists, particularly in the private media, operate in dire economic conditions, resulting from low salaries, absence of health insurance and social security benefits. For this reason, requesting or being offered money and other material benefits to cover specific news is a widespread malpractice. Corruption thrives in this environment. For many media organizations and journalists, corruption is a means to survive. The difficult working conditions for journalists also mean that a commitment to professionalism and ethical journalism is not a priority for most journalists. This study argues that within this context, not only is the credibility of the profession damaged, there is the collapse of independent, accurate and objective journalism. The role of the media as a public watchdog and investigative journalism are seriously undermined.
\end{abstract}

Keywords: Demographic profile, work conditions, Journalist Survey, Cameroon

\section{INTRODUCTION}

The constitution of Cameroon guarantees free speech, though genuine freedom of expression remains elusive in daily life. As part of its democratization process which started in 1990, new laws relating to freedom of the press and association were enacted. In December 1990, government passed the Freedom of Mass Communication Law liberalizing the media sector. The outcome of the law was a newspaper publishing boom in the country. A 2003 report for the Commonwealth Press Union revealed that 654 newspapers were registered in the country in 1997 (Ndangam, 2006). Ndangam (2006) argues that while the flourishing private press reflected the hankering of a budding politically conscious readership and duly served as a tool for mobilizing public opinion and support, the majority of these publications appeared sporadically and very few survived longer than a couple of months or a particular event.

On January 4, 1996, Law No. 96/04 was promulgated, modifying certain provisions of Law No. 90/052 of December 19, 1990. How appropriate has the new law been in fostering press freedom and improving the working conditions of Cameroonian journalist? The modification of the law has not stopped the authorities from exercising legal methods to harass journalists nor has it provided media proprietors with a viable economic environment for financial autonomy and professional independence. The craving for control, the selective application of the law has made newsgathering and reporting very difficult for journalists. Thus if one were to take into account the degree of persistent censorship, seizures, bans, confiscations, searches and raids on media houses, harassments, arrest and detention of

Corresponding Author: pngangum@ulb.ac.be 
journalists, the 2008 government crackdown on the broadcast media, as well as the precarious working conditions of journalists, then it would be lopsided to reason that the December 1990 media law and its slight modification in 1996 changed much in practice.

According to an incisive report by the Federation of African Journalists (FAJ), journalists do not benefit from any health or safety protection and rarely have health insurance. They do not even receive the necessary basic equipment to help them protect themselves in situations of conflict or during unrest (FAJ, 2010). How many Cameroonian journalists for example had basic safety equipment when covering the 2008 nationwide protests and demonstrations? How many have combat helmets which provide effective protection against flying objects and protection against riots and rock throwing. How many journalists have adequate safety equipment (bulletproof vest, telecommunication tools, first aid kits, and if possible armored vehicles at their disposal) when travelling or operating in hostile, high-risks environments? How many have received training and counseling in minimum security measures before covering a demonstration or riot as the one mentioned above.

How many Cameroonian journalists have an insurance policy to cover illness, disability, loss of life, injuries derived from an assignment or will provide support to their family in case they disappear? As we shall read later this paper, a surprisingly high number of journalists from Africa (Cameroon), do operate without any health insurance policy. In such cases, journalists who are injured, even on the job, may not be able to rely on their news organizations to cover their medical expenses. Journalists, especially those of the private media are not only poorly remunerated, they don't benefit from any effective labor legislation, employers rarely offer contracts, collective bargaining agreements (CBA), free transport, effective office telephone, fax and computer services. Though a CBA was signed in 2008, its positive effects are still to be felt. In fact, it is more appropriate to speak of individual bargaining since almost all private media journalists negotiate their employment and pay alone.

The public or state owned media in Cameroon has been and still is an integral part of the civil service. The government ensures that this media think of themselves more as a part of the central administration than as a separate institution and profession. The integration of the state owned media into the civil service was part of the process of political socialization devised by government to ensure loyalty and subservience from all state employed journalists. By assuming the role of gatekeeper and paymaster of all state employees, the government succeeded to procure itself an effective weapon for exacting unflinching loyalty and subservience from all state employed journalists (Nyamnjoh, 2005).

If the government was able to undermine pluralism in the public media by making state employed journalists civil servants, it stifled the private press with draconian press laws. According to Frère (2014), vague formulations of the law often lead to abusive interpretations, allowing courts to inflict disproportionate sentences on media organizations and journalists that the authorities wish to silence. Journalists who disclose cases of corruption, professional misconduct, scandals involving civil servants, police, army and members of parliament; journalists who criticize government policy and public spending can be accused of libel or posing as a threat to national unity and security, or attempting to destabilize the institutions. Even the health of the president can invoke the fury and repressive hammer of the state. For example, in 1997 the editor of ' $\mathrm{Le}$ Messager', Pius Njawe was imprisoned for having invoked the health of President Paul Biya.

According to Kouyo (2010), there is a general lack of concern and interest of employers and governments regarding the safety of journalists. Overall, the working conditions of journalists, especially journalists of the private media are precarious, with low salaries, no protection against unfair dismissal and frequently with no contracts (Fanucci et al, 2008). Many journalists are paid below the minimum wage (which is $28.000 \mathrm{FCFA}$, the equivalence of less than 50 Euros), while some of them are not paid for more than a year (Ndangam, 2006).

While the issue of the deplorable working conditions of Cameroonian journalists has captured the popular imagination and triggered comments from various analysts, there is not much academic literature that focuses precisely on the subject as it relates to the nation's media professionals. The paucity of literature 
on this very important subject informing the media landscape in Cameroon needs to be addressed because how other economic and political institutions and the body politic in general perceive, interpret and respond to the issue is consequential for improving, building a media system that is able to assume its role in Cameroon's turbulent, shaky and evolving democracy.

Frère (2014) contends that though there is a wide range of research based on content produced by African journalists and disseminated by their media, the parameter of the context in which journalists do operate or practice their professional activity and the possible impact on the risks they face on the content they produce are often not taken into account. Better identification of those risks can therefore help not only to better understand what it means to be a journalist in Africa (Cameroon) but also to shed another light on media content. Thus the aim of this article is therefore not only to provide a demographic profile of Cameroonian professional journalists but also to examine the working conditions of the journalists, the difficulties that they face in their daily operation in order to check whether and how these difficulties can be prevented, mitigated or even compensated.

Exactly who Cameroonian journalist are and precisely under which kind of working conditions they operate in the building of a modern Cameroonian society is largely speculative. This current study aims to mitigate the situation. This study contends that the evolving practices of journalism in Cameroon demand more scholarly attention than they have received in recent years. This will not only help us to understand journalists' frailties but it will give us a deeper sociological account of how Cameroonian journalists do journalistic work as well as the conditions under which they operate. Studies of this kind would be relevant in providing factual information based on evidence. Thus a study of the demographic profile and working conditions of Cameroonian journalists is useful in moving beyond generic generalizations about the media and the people who work for the media.

According to Mwesige (2004), national portraits of journalists are important because journalism is deemed a central influence on society. As Hyden \& Leslie (2002) has maintained, although several aspects of democratization in Africa have received increasing scholarly attention in recent years, not enough systematic inquiry has been directed at the role of the media in this process or the people who man this industry. An appreciation of the role of journalism in Cameroon cannot be complete without a valuable understanding of the people who work in this institution. As Weaver (1998) succinctly puts it:

'The major assumption is that journalists' backgrounds and ideas have some relationship to what is reported (and how it is covered) in the various news media around the world, in spite of various societal and organizational constraints, and that this news coverage matters in terms of world public opinion and policies'.

\section{RESEARCH QUESTIONS}

Within the context of Cameroon's brief press history, this article provides answers to the following research questions:

RQ1. What is the demographic profile of Cameroonian journalists?

RQ2. What is the current work situation of Cameroonian journalist?

By addressing these questions, this study produces some benchmark information about journalism in Cameroon. This is a significant and critical period for Cameroon's transition from a one party state to a multiparty democracy and from state monopoly, heavy control over the media to media liberalization.

\section{METHOD}

The researcher visited major newspapers, broadcasting stations in the country's major cities of Yaoundé, Douala, Buea, Kumba, Limbe and personally distributed paper questionnaire to 705 journalists between July 2010-April 2011. At each location, the researcher dropped enough questionnaires so that each journalist could complete one in time to be picked up later. Questionnaire was delivered via electronic mail to some few journalists who opted for this channel.

The questionnaire was pretested on a sample of journalists, 18 Anglophone and 15 Francophone journalists in July-August 2010. Following Weaver \& Wilhoit (1986:168) this study defined journalists as 'those who have the responsibility for the preparation 
and transmission of news stories and other information'. In other words, the population of the survey is all full-time reporters, writers, editors, columnists, correspondents, photojournalists etc.

In total, 400 Cameroonian journalists out of the 705 had completed the questionnaire from July-August 2010 when the questionnaires were pretested, September-December 2010 when the questionnaires were administered to journalists and April ending 2011 when the data collection phase of the research became closed. This gives a response rate of $57 \%$. 365 journalists completed paper questionnaires while 35 completed the questionnaire by electronic mail (internet).

This study argues that though the latter was meant to supplement the former, the differences in response rate between the two mediums are significant. With low internet connectivity in Cameroon, unstable power supply, raising internet costs, the internet (web) is not a suitable or effective tool for survey research. The disparity in response rate is therefore a glaring testament that Cameroonian journalists prefer office-office personal contact and the delivery of questionnaires for self completion than completion via the web or internet.

\section{KEY FINDINGS}

This section discusses the findings of the survey. It begins by delineating the demographic profile of Cameroonian journalists before moving on to discuss their current working conditions.

\section{Demographic Profile}

Most Cameroonian professional journalists were born in Cameroon of Cameroonian parents. A majority of respondents were male $(60 \%)$, with $40 \%$ being female. $59 \%$ of the respondents indicated they were Francophone, $40.5 \%$ are Anglophones. The issue of language is significant. Cameroon's two main official languages are the English and French languages. The policy of official language bilingualism constitutes the main core of Cameroon's language policy. Article 1, paragraph 3 of the Constitution of 18 January 1996 clearly states that:

'The official languages of the Republic of Cameroon shall be English and French, both languages having the same status. The State shall guarantee the promotion of bilingualism throughout the country. It shall endeavor to protect and promote national languages'.

Successive Constitutions since independence have reiterated the relevance of pursuing a policy of official bilingualism. However, there exists no welldefined language policy till date as to its implementation and monitoring. Even more, though English and French are considered to be equal in status according to constitutional arrangements, French has a de facto dominance over English in the areas of administration, education and the media. In fact, it is not an exaggeration to say that French influence as expressed in language, culture and political policy prevails in all domains (Wolf 1997: 421).

\section{Gender}

It is not uncommon to see that in most media organizations in Cameroon, men out-number women at the reporting and editorial levels. This trend has been revealed by similar studies in Nepal, Ethiopian, Uganda mentioned elsewhere in this study. At the management level, women are almost invisible. $60 \%$ of the respondents for this study were reported to be 'male', while $40 \%$ were 'female'. At the management and decision making levels, women are almost invisible. For example, when we look at all the main private newspapers in Cameroon, no woman is a publisher, a proprietor or station manager of any of the private broadcasting stations across the country. With regards to the public media, we don't find any major difference. Though women constitute a majority of students in most of Cameroon's journalism training institutions, this is not reflected in the media's labor market (Tanjong, 2012). In editorial departments, the issue of gender is also discernible as men and women tend to be associated with different kinds of stories. In Cameroon for example, the Unity Palace (presidential residence), Glass House (National Assemble), International Relations and Politics are national beats solely for men, while women are more into health, cultural and economic beats. Even when women are assigned to the Unity Palace, it is mainly for soft news such as covering socio-cultural activities of the President's wife. 


\section{Age and Job Experience}

$44.0 \%$ of the respondents were born between 1970 79 , $36.3 \%$ between $1980-89$ and $19.8 \%$ between 1960-69. As concerns journalism job experience, $30 \%$ of the respondents indicated that they had a work experience from 6-10 years, 26.5\% 11-15 years and $20.8 \% 1-5$ years. In terms of age composition and job experience, study results revealed that journalism appears to be a young person's profession in Cameroon since a majority of the journalists had an age range of 22-41 years. This results is consistent with those of similar studies conducted in Nepal (Ramaprasad and Kelly, 2003); Birhanu (2014) study of Ethiopian journalists.

A significant number $(80 \%)$ of respondents in this study were born between $1989-1970$ while $50 \%$ of the respondents had a job experience ranging from 110 years. These findings reveal significant personnel dynamics informing the profession. First, it can be explained at least partly to the sudden and dramatic increase in media outlets following the 1990 media reforms and the passage of the broadcasting decree in the year 2000. This media liberalization that swept across the country culminated in an increased demand for journalists. This study argues that majority of the respondents had worked for 10 years or less and therefore only knew the working conditions of a free media environment.

Furthermore, $26 \%$ of the respondents had a journalism job experience of 11-15 years, and only $17 \%$ had a job experience of 16-25 years. The implication of these results is that journalism in Cameroon was still slow to attract, retain the best and learned minds, that journalism was losing most of its veterans, experienced experts and educators to more lucrative sectors. I submit that this tendency appear to militate against the institution. However, this problem is not solely a Cameroonian syndrome. Birhanu (2014) has indicated in the study of Ethiopian journalists a significant turn-over of experienced personnel, possibly due to meager wages and other external influences over the profession.

\section{Education and Training}

Several journalists received education and training before and during their jobs at various domestic and foreign institutions. The survey results indicated remarkable progress in the educational qualifications of journalists. Most journalists in Cameroon hold a bachelor's degree in journalism or mass communication. $64.3 \%$ of the respondents had graduated from the university, $25.3 \%$ from a higher institution of professional learning and $10.5 \%$ from some other tertiary institution, $12.0 \%$ had on the job training, while $1.8 \%$ reported having 'no education' in journalism. In addition, $85.8 \%$ of respondents thought a university degree in journalism and communication was significant to today's journalists; $89.8 \%$ indicated that it was of 'significance' as well to future journalists.

The above results are consistent with those of similar studies carried out across the continent and elsewhere in the globe. For example Ramaprasad and Kelly (2003) survey of Nepalese journalists revealed that several journalists had received training before and during their jobs at various national and foreign institutions. Birhanu (2014) found dramatic progress concerning the workforce qualification of Ethiopian journalists. Same is true with Mwesige (2004) study of Ugandan journalists.

The results from Cameroonian journalists appears to suggest that, compared to their peers in the western world especially Britain 'where a journalist is born, not made', Cameroon places importance on journalism education in formal schools of training. According to a survey of British journalists, while $49 \%$ had a degree, $20 \%$ pursuing 'tertiary education', $30 \%$ had no exposure to tertiary education and only a meager $2 \%$ of all those who had a degree took undergraduate courses in journalism (Henningham \& Delano, 1998). But as we are going to discern below, I argue that this trend is shifting to recognition of the nature and benefits of university education for journalists.

As regards Cameroon, formal education, training programmes in journalism started in 1970. In that year, Cameroon together with Gabon, Central Africa Republic, Rwanda, Chad and Togo collectively set up 'L'ecole Superieure Internationale de Journalisme de Yaoundé (ESIJY) Cameroon. In 1982, the institution was nationalized and became L'ecole Superieure des Sciences et Techniques de L'information (ESSTI). In 1991, the institution became L'ecole Superieure des Sciences et Techniques de L'information et dela Communication (ESSTIC)-Advanced School of Mass Communication. Also, there are three University departments offering journalism study programmes, 
two of these institutions are private, that is 'Siantou Superieure' as well as 'Institute Ndi Samba', then the department of Journalism \& Mass Communications, University of Buea which is a public institution since 1993.

Thus, over the years, many journalists without formal education in journalism have sought to acquire university degrees. The proliferation of public and private journalism education and training schools in Cameroon as well as in other countries across the region epitomizes a dramatic shift in reasoning as to the nature, relevance and benefits of journalism education and training.

\section{Political \& Religious Affiliations}

Most of the respondents said they had a political affiliation, were religious and had been brought up under a particular faith. $51.3 \%$ reported being Catholics, 20\% were either raised as Protestants, Baptists, Presbyterians and 5\% as Muslims. 57.0\% found religious beliefs to be 'very important'. Asked what they thought of some daily news organizations manifesting a marked ideological, regional or ethnic point of view, $37.8 \%$ of respondents reported 'a good idea', $43.5 \%$ indicated 'bad idea', while $18.8 \%$ was 'neutral' as the table 10 demonstrates.

Concerning where Cameroonian journalists situate themselves politically, $26.5 \%$ of the respondents reported 'progressive', $21.8 \%$ said they were 'moderate progressive', $26.5 \%$ indicated being at the 'centre'.
Whether the political, ideological and religious views of journalists have an impact on the way they do their job remains an interesting subject for future research. However, many journalists indicated that religious orientation seems to have a strong influence on them when it comes to shaping ideas in matters of journalism ethics. Thus, $40.0 \%$ of respondents were of the opinion that religious background has been 'extremely influential' in shaping their ideas in matters of journalism ethics, while $33.5 \%$ reported 'quite influential'.

\section{Current Work Situation}

Most respondents (91.3\%) indicated working 'fulltime' either for newspapers, news magazines, radio and television. A majority of them that is $35.5 \%$ work for 'radio stations', $30.5 \%$ for 'television' and $21.0 \%$ 'newspapers'. Following the 1990 media reforms and the passage of the broadcasting decree of the year 2000 , a proliferation of private radio and television stations sprouted, generating an influx of new graduates into the labor market.

\section{Workload and Flexibility}

Journalism is a very demanding and exhaustive profession. As regards working hours and work pressure, $40 \%$ of respondents reported working more than 55 hours a week; $37.8 \%$ working 45-55 hours a week. The table below gives us a general overview of the number of hours that journalists work per-week.

Table 1: Number of Hours Work Per Week

\begin{tabular}{lllll}
\hline & Frequency & Percent & Valid Percent & $\begin{array}{l}\text { Cumulative } \\
\text { Percent }\end{array}$ \\
\hline Less than 25 Hours & 33 & 8,3 & 8,3 & 8,3 \\
\hline 25-35 hours & 16 & 4,0 & 4,0 & 12,3 \\
\hline 35-45 Hours & 40 & 10,0 & 10,0 & 22,3 \\
\hline 45-55 Hours & 151 & 37,8 & 37,8 & 60,0 \\
\hline More than 55 Hours & 160 & 40,0 & 40,0 & 100,0 \\
\hline Total & 400 & 100,0 & 100,0 & \\
\hline
\end{tabular}

Also, most often, journalists have to work extra hours; work in the evenings, at nights and even during the weekends. Despite the increased working hours, intensive nature of journalistic work and the fact that most journalists in Cameroon operate under very difficult working conditions, 'loan' has been and still is a major issue. 
Loan

The increased working hours have not been met with a corresponding increase in wages as well as improved working conditions for journalists. The table below highlights the salary scale of Cameroonian professional journalists.

Table 2: Salary Scale of Cameroonian Journalists (1 Euro is approximately 655 Cameroon Franc CFA)

\begin{tabular}{|c|c|c|c|c|}
\hline & Frequency & Percent & Valid Percent & $\begin{array}{l}\text { Cumulative } \\
\text { Percent }\end{array}$ \\
\hline 50.000F CFA & 8 & 2,0 & 2,0 & 2,0 \\
\hline 50.000-65.500FCFA & 53 & 13,3 & 13,3 & 15,3 \\
\hline 65.500-131.000FCFA & 108 & 27,0 & 27,0 & 42,3 \\
\hline 131.000-262.000FCFA & 121 & 30,3 & 30,3 & 72,5 \\
\hline 262.000-393.000FCFA & 77 & 19,3 & 19,3 & 91,8 \\
\hline 393.000-524.000FCFA & 28 & 7,0 & 7,0 & 98,8 \\
\hline 524.000-655.000FCFA & 2 &, 5 &, 5 & 99,3 \\
\hline 655.000-786.000FCFA & 3 &, 8 &, 8 & 100,0 \\
\hline Total & 400 & 100,0 & 100,0 & \\
\hline
\end{tabular}

Drawing from the above table, this study argues that as in many parts of the world, journalism is not lucrative in Cameroon. The issue of loan is not peculiar only to Cameroonian journalists. According to Weaver \& Willnat (2012), in Chile the strongest predictors of job satisfaction or the lack of it were pay and the chance of journalists to use all their abilities and knowledge. In Malaysia, pay is crucial, while in Brazil, low pay is a predictor of job dissatisfaction.

Journalists, especially those working for the private media are poorly remunerated by their employers. Thus there is a tendency for these journalists to request payments in cash, other material benefits from individuals and organizations that they cover (see Alobwede, 2006, pp. 27, Ndangam, 2006, Nyamnjoh, 2005). Thus, debates informing the need of improved working conditions for journalists have increased in recent years culminating in the 2008 signing of the National Collective Convention of journalists.

\section{National Collective Convention (NCC)}

On November $12^{\text {th }}$, 2008, a National Collective Convention of journalists and related professionals in the Social Communication sector of Cameroon was signed by press entrepreneurs and journalists in the presence of representatives of the Ministry of Communication and the Ministry of Labor and Social Security. Article 29 of the Convention defines 12 categories of press employees, from workers performing elementary tasks demanding no professional knowledge or adaptation to the senior manager in charge of supervising and controlling the copy editors and managing editors; experimented production manager in charge of supervising and controlling programmes; advisory engineer supervising all technical equipment and advising management; experimental senior manager capable of leading a team and replete with public relations skills.

The salaries fixed by the 2008 Collective Convention for the aforementioned 12 categories of workers range from FCFA 32.865 (50Euros) to FCFA 430.395 (657 Euros). Journalists defined in categories 
8-9 are defined as 'agents responsible for a precise task in the quest for, analysis of and treatment of information, the drafting of articles, the organization and conception of production and dissemination equipment as well as production and realization and continuation'. They should at least have a 'Baccalaureat or School-Leaving Certificate'. With two years of higher education, the Convention perceives them as 'confirmed journalists' with the status of a 'middle manager'. Their salaries range from FCFA 161.645 (246Euros) to FCFA 293.460 (448Euros).

The Convention is in following with Article 52 of the Cameroon Labor Code, which aims to ensure permanent social dialogue between employers and workers in this domain, with the overriding aim of guaranteeing the protection of their interests like their professional rights, contracts, working conditions, salaries or mode of payment, health and social security entitlements, which employers have up to now flouted due not only to the ignorance of journalists but particularly because there has been no trade union to ensure these rights are respected.

According to Fanucci et al (2008), by setting common standards for journalists of both the public and private media, the NCC will contribute to the erosion of the existing cleavage. The Convention also determines journalists' rights (regardless of whether they are part of a trade union) in relation to minimum salary, holidays and sick leave. An arbitration court would consider disputes and have the authority to impose sanctions. Fanucci et al (2008) argues that although the state has the responsibility of ensuring the implementation of the Convention, it remains to be seen whether it will be properly implemented and enforced. Indeed, there are hardly any media organizations in Cameroon who can afford to uphold or comply with all the requirements of the Convention. This point has been highlighted in the study of Atenga (2012). According to Atenga (2012) the average salary for journalists working in the following newspapers is as follows:

Table 3: Average salary for journalists

\begin{tabular}{ll}
\hline Newspaper Title & Average salary \\
\hline L'Achu New & 100.000 FCFA \\
Page Group & (153 Euros) \\
Le Jour & 120.000 FCFA
\end{tabular}

\begin{tabular}{ll}
\hline & (185 Euros) \\
La Nouvelle & 120.000 FCFA \\
Expression & (185 Euros) \\
Le Messager & $\begin{array}{l}\text { 100.000 FCFA } \\
\text { (153 Euros } \\
\text { 130.000 FCFA } \\
\text { Mutations }\end{array}$ \\
& 90.000 \\
Le Popoli & (140 Euros) \\
&
\end{tabular}

Table. 3 indicate the average salary for journalists and by extension suggest that the newspapers meet the minimum norms set by the NCC. However, Atenga (2012) maintains that the reality in the field is quite different. Indeed, between the salaries declared by media owners and those actually received by the journalists and other members of staff, the gap is sometimes quite substantial. Even more, these modest salaries are not always paid on time, if at all. With the exception of 'La Nouvelle Expression', all dailies have delays in payment from 2-9 months. None is up to date concerning social security contributions for its employees. Very few journalists benefit from private health insurance. Amidst the grim working conditions, many journalists are afraid to claim that they are being exploited. According to Charles Nforgang (2009) as cited in Atenga (2012, pp.21), since the inception of the National Collective Convention, 'the text has been evoked neither by journalists, who fear being fired wrongly, nor the media proprietors, who expect aid from the state which is not provided by the Convention'

\section{Impact of Poor Working Conditions}

Though efforts have been made to enhance selfregulation, journalists' pay and working conditions continue to lag behind. The creeping decline in journalists' pay and working conditions may undermine the reputation of the media industry. For instance, in Cameroon, this has generated two types of corruption within the media: There is hardcore corruption, that is when journalists use their power to blackmail people about whom they have sensitive information; or journalists receive payments from influential sources in order to either kill or put a positive spin on stories. According to Lush et al (2012) an increasing number of journalists and publishers in Cameroon practice investigative 
blackmail. Furthermore, some media organizations simply don't pay at all, and encourage their reporters to live on transport money from news sources and event organizers.

The second type of corruption is variously referred to as 'Participation Fee, Motivation Fee, Gombo, and Final Communiqué in Cameroon. This ranges from bribes or gifts in return for positive coverage of specific issues and events, to journalists receiving transport, food and accommodation allowances from the organizers of events they cover. Some journalists are so poorly paid or not paid at all that they rely fully on these allowances to survive (Lush et al, 2012). Ndangam (2006, 2009) observes that a significant number of journalists in Cameroon live entirely on 'gombo' payments and have perfected their strategies to approach the sponsors.

According to Voltmer (2013), corruption in journalism is rife in societies built on a strong patronclient relationships and where huge income inequalities abound. The exchange between a patron and a client journalist is therefore seen as part of a system of mutual responsibilities that is believed to benefit both parties. As one Cameroonian journalist puts it, 'gombo means helping me to help you' (Ndangam, 2009: 826). The practice appears to be widespread in Cameroon. Thus, when asked whether Cameroonian journalists accept money, gifts and other forms of material benefits as a requirement for event coverage, $55.8 \%$ of the respondents indicated that they 'agree', while $22.5 \%$ said they 'disagree'. Furthermore, when asked whether in the last 3-6 months they had received money or material benefit as a requirement for event coverage, $43.3 \%$ of the respondents indicated 'Yes' and $56.8 \%$ said 'No'. $43.3 \%$ of the respondents indicated that bribery and corruption of journalism ethics was 'very common', $41.8 \%$ said 'fairly common'.

Though it is easy to condemn the practices of paid journalism, it is relevant to understand what circumstances journalists are prepared to accept favors as a requirement for commissioned content. Though the transaction takes place between individuals, paid journalism remains a structural problem that has to be understood within the politico, cultural and economic contexts in which it occurs (Voltmer, 2013).

\section{CONCLUSIONS}

Journalism appears to be a young person's profession in Cameroon. This result is consistent with those of Weaver \& Willnat (2012) which concluded that journalism tends to be a young person's occupation, with most journalists between 25 and 45 years old. The average age of journalists ranges from 32-53 in the 29 surveys reporting it. In most places, journalists are younger on average (39 years old) than is the work force in general. A significant number (80\%) of respondents in this study were born between 19891970 (22-41 years) while $50 \%$ of the respondents had job experience ranging from 1-10 years.

Furthermore, $26 \%$ of the respondents had a journalism job experience of 11-15 years, and only $17 \%$ had a job experience of 16-25 years. The implication of these results is that journalism in Cameroon was still slow to 'attract, retain the best and learned minds', that journalism was losing most of its veterans, experienced experts and educators to more lucrative sectors. This tendency appears to militate against the institution. According to Weaver \& Willnat (2012), in many countries, young people become journalists in order to gain experience before leaving for more lucrative and stable jobs in other fields, especially Public Relations. This seems to be a fairly common pattern around the globe. This theme has been illuminated by Okigbo (2002).

The progress recorded by Cameroonian journalists regarding their professional qualification presupposes that journalism education is increasingly being seen as professionally relevant to entry-level and midcareer journalists looking to improve and upgrade their qualifications. Thus, over the years, many journalists without formal education in journalism have sought to acquire university degrees. However, although most Cameroonian journalists hold a college degree, this is not the case in several countries across the globe as demonstrated by Weaver \& Willnat (2012) 'The Global Journalist in the 21st Century'. Even more, it is less typical for journalists to be graduates of journalism programmes in college. Thus of the 25 countries reporting on this figure, the average is $42.5 \%$. Only 8 countries reported more than half of their journalists had majored in journalism. In the 17 countries reporting this proportion, most did not exceed one third. Most 
journalists are not graduates of college level journalism programmes in this sample of nations.

This study argues that as in many parts of the world, journalism is not lucrative in Cameroon. The results of the study is consistent with Birhanu (2014) and Ramaprasad and Kelly (2003) Mwesige (2004) studies of Ethiopian, Nepalese, and Ugandan journalists respectively. $93 \%$ of Ethiopian journalists receive approximately $72-287$ USD while the mean monthly income of journalists in Nepal is estimated to 113.58 USD. In Cameroon, the basic salary of a junior reporter at the state broadcaster (Cameroon Radio \& Television-CRTV) ranges between 160.000FCFA and 175.000FCFA including benefits. The salary of degree holders recruited by the state media range between 300.000FCFA and 350.000FCFA, while senior journalists and those with postgraduate qualifications earn up to 400.000FCFA. Thus, state media employees enjoy a pay package and privileges which falls within margins of appreciation as compared to their peers in the private media. Journalists, especially those working for the private media are poorly remunerated by their employers. Thus there is a tendency for these journalists to request payments in cash and other material benefits from individuals and organizations that they cover-a travesty of journalistic codes of ethics (see Ngangum, 2015; Alobwede, 2006, pp. 27, Ndangam, 2006; Nyamnjoh, 2005).

Drawing from the results of the survey, journalism is a very demanding profession in Cameroon. According to Tanjong (2012), it requires working at night and for long hours out of home. It also entails long distance travelling. By the same token, Ramaprasad and Kelly (2003) study of Nepalese journalists indicated similar concerns. Their study revealed that there is fear among parents that because of late and uncertain hours and travel, journalism may not be a safe profession for women.

This study argues that press freedom and professional journalism thrives where the state takes suitable measures through effective laws and practice not only to protect journalists but also to improve their working conditions. In this way, the state becomes a reliable guarantor of media pluralism and freedom of expression. In order to comply with this obligation, it is important for the state to put in place a sufficient legal framework to ensure improved working conditions for journalists but the $2008 \mathrm{NCC}$ failed to provide the relevant structure and framework. More so, this paper contends that since 1982 till present, when one political party, Cameroon People Democratic Movement (CPDM) dominated politics, exercising firm control over parliament, presidency, government and media, it cannot be gainsaid that existing domestic law have not succeeded in providing a guarantee of improved working conditions for journalists. Thus, while the December 1990 media law, the 2000 audiovisual decree and the NCC are seen as important milestones, they did not mitigate the problem.

\section{REFERENCES}

Atenga, T. 2012. Cameroon's Private Daily Press: In Search of a viable Economic Model. Ecquid Novi, 33(3), 13-29

Alobwede, C.E. 2006. African Media Development Initiative-Cameroon. London. BBC World Service Trust

Berhanu L. (2009). Freebies and brown envelopes: The case of Ethiopian broadcast media. Saarbrücken: VDM Verlag.

Berhanu L. and Skjerdal, T.S. (2009). Freebies and brown envelopes in Ethiopian journalism. Ecquid Novi - African Journalism Studies, 30(2), 134-54.

Birhanu O. (2010). Bribery journalism in Ethiopia: Manifestations and factors. African Communication Research, 3,475-496.

Birhanu, O. 2014. Pride versus Humility. The SelfPerceived Paradoxical Identities of Ethiopian Journalists. Sage.

Fanucci, F. \& Federica Prina. 2008. Scoping Study on Freedom of Expression in Cameroon. Global Partners \& Associates.

Federation of African Journalists (FAJ). 2010. Workshop on Security and Protection of African Journalists, 2-3 September, Addis-Abba.

Frère, M-S, 2014. Journalist in Africa: A high-risk profession under threat. Journal of African Media Studies, Vol 6(2), pp.181-198.

Hyden, Goran, and Michael, Leslie. 2002. Communications and Democratization in Africa. In Goran Hyden, Michael Leslie, and Folu F. Obundiumu (Eds), Media and Democracy in Africa. Uppsala: Nordiska Afrikainstutet, pp. $1-27$.

Jyotika, R. 2001. A Profile of Journalists in Post Independent Tanzania. Gazette, Vol. 63(6) 539-555.

Jyotika, R. \& James D. Kelly. 2003. Reporting the News from the World's Rooftop. A Survey of Nepalese Journalists. Gazette, Vol 65(3) 291-315.

Jyotika, R. 2003. The Private \& Government Sides of Tanzanian Journalists. The Harvard International Journal of Press/Politics, Vol. 8, No. 1. Pp. 8-26. 
Kouyo, A. 2010. Second AFJ Congress in Harare-African Journalists thinking about their working conditions.

Lush, D, Mareike Le Pelley and Kerstin Funck. 2012. SelfRegulation, Working Conditions and Corruption in African Journalism. Friedrich Ebert-Stiftung.

Lush, D. 1998. 'The Role of the African Media in the Promotion of Democracy and Human Rights'. In S. Kayizzi-Mungerwa, A.O Olukoshi, and L.Wohlgemuth (Eds), Towards a New Partnership with Africa: Challenges and Opportunities, Uppsala: Nordiska Afrikainstitutet, pp.42-65.

Mwesige, P.G. 2004. Disseminators, Advocates and Watchdogs: A Profile of Ugandan Journalist in the new Millennium. Journalism 5(1): 69-96.

Ndangam, L.N. (2006). 'Gombo': Bribery and the corruption of journalism ethics in Cameroon. Ecquid Novi, 27(2), 179-99.

Ndangam, L. (2009). "All of us have taken Gombo": Media pluralism and patronage in Cameroonian journalism. Journalism, 10(6), 819-42.

Ngangum, P.T. 2015. Cash and Gifts for Coverage: Bribery and Corruption of Journalism Ethics in Cameroon. Paper Presented at the 3rd International Conference on Media Ethics. School of Communication. University of Seville, 24-26 March, 2015.

Okigbo, Charles. 2002. Media in Africa. In Module 3, Unit $16 \mathrm{~b}$ of the MA in Mass Communications (By Distance Learning), Centre for Mass Communications Research, University of Leicester.
Tanjong, E, 2012. Media Balance in Sub-Saharan Africa's Fragile Democracy. Analysis of Journalism Practice in Cameroon. Limbe. Design House.

Voltmer, K. 2013. The Media in Transitional Democracies. Cambridge. Polity Press.

Weaver, D., \& Willnat, L. (Eds). 2012. The Global Journalist in the 21st Century. New York, NY: Routledge.

Weaver, D. \& Wilhoit G. Cleveland (Eds). 1996. The American Journalist in the 1990s: US News People at the End of an Era. NJ. Lawrence Erlbaum Associates, Inc, Publishers.

Weaver, D. \& Wilhoit, C. G. 1986. The American Journalist. Bloomington, IN: University of Indiana Press.

Wolf, Hans-Georg (1997): "Transcendence of Ethnic Boundaries: The Case of the Anglophones in Cameroon". Journal of Sociolinguistics 1(3): 419-426. 